presentation of a case that every biologist seems to have to argue, or to have argued, on his behalf.

The biographies fall into two categories. some are appreciations, sympathetic and yet critical, of botanists of international repute, such as Schleiden and Nägeli ; others are intimately told stories of Errera's colleagues in the scientific world of Belgium. These form at one and the same time valuable contributions to the history of science and human portraits, the sincerity and inward vision of which give them a quality of universal appeal, whether their subjects be little-known Belgian botanists or chemists of international repute such as Stas, who was sufficiently a prophet in his own country to be entertained by the Bishop of Namur, though he insisted upon bringing a Jesuit father with him and in eating " bifsteak" upon a Friday.

\section{Medical History of the War.}

History of the Great War: Based on Official Documents. Medical Services: Pathology. Edited by MajorGeneral Sir W. G. Macpherson, Major-General Sir W. B. Leishman, and Colonel S. L. Cummins. Pp. vi +600 . (London: H.M. Stationery Office, I923.) 2xs. net.

7 HIS volume is the final one of the purely medical 1 series dealing with the diseases and hygiene of the great War. It may appear to be a matter of doubt whether it was desirable to separate in different volumes the symptoms and treatment of individual diseases from their pathology, but that is the course which the editors have pursued. The result is that every subject is disjointed, and it will not always be a simple task for those who consult these volumes in future to fit the pieces into their proper places.

The present volume deals with the pathological side of many conditions, such as wounds, tetanus, enteric fevers, dysentery, cerebro-spinal fever, influenza, tuberculosis, trench fever, spirochætal jaundice, polyneuritis, nephritis, gingivitis, and encephalitis lethargica. As in works with many contributors, there is a lack of unity which the editors have not succeeded in dispelling. After the prolonged period which has elapsed since the termination of the War, and as the work is stated to be "based on official documents," one would have expected greater harmony and detail, which would have gone to make this a standard work. Instead, it is really a collection of individual essays by twenty-three contributors, mostly civilian, who had been called together to complete the work.

In a heterogeneous collection of papers such as this is, it is perhaps invidious to single out individual contributors, but after a careful study the reviewer considers that the essay on the physiology of wounds by
Sir Almroth Wright and that on amœbic dysentery by Mr. Clifford Dobell are of outstanding merit. In that of Wright we have one of the great researches of the War, full of ingenuity and rich in idea, which characterises all his work; whereas Mr. Dobell's essay is a model for other workers by a master of his subject.

One of the editors, Sir W. B. Leishman, contributes an introductory chapter on the organisation of the pathological service. $\mathrm{He}$ also writes a general paper on the enteric fevers, which suffers from having lost its bibliography during the composition of the book. This hiatus is, however, supplied in a special leaflet, but with a separate pagination. The other bibliographies are short but accurate, and in some cases the authors have dispensed with the trouble of compilation and have adopted the easier method of referring to the work of some one else in a foreign language.

W. B.

\section{Anthropology and Colonial Administration.}

The Lango: a Nilotic Tribe of Uganda. By J. H. Driberg. Pp. $468+\mathrm{I} 2$ plates. (London: T. Fisher Unwin, Ltd., I923.) 635. net.

7 HE work before us is an excellent example of a happily increasing class of literature which bears great tribute to the value of anthropological studies in colonial administration. In the old days, young men went out to administer primitive peoples with no more experience than that afforded by the public school. Fortunately for England, the mode of thought, ideas of justice, and general social propriety current in the public school are so near to that of primitive man that the new administrator made far fewer mistakes than might have been expected. But there is no denying that the advance of anthropological science has assisted the colonial administrator, and this fact has been recognised by the British Colonial Office in its inclusion, in the Tropical African Services course, of a series of lectures on social anthropology.

Mr. Driberg's book is just that response to an elementary anthropological training which justifies anthropology. Indeed, it goes further than that, for $\mathrm{Mr}$. Driberg is an anthropologist, and is gifted with two rare qualities: the sympathetic understanding, and the faculty of clear expression.

The Lango are an important tribe of Nilotic negroes inhabiting the Nile province of Uganda. Mr. Driberg deals with them faithfully : their history, environment, physical characters, occupations and daily life, social organisation, religion and magic, and language. The linguistic section consists of a grammar, Lango-English and English-Lango vocabularies, and a very interesting series of fables, reproduced in double columns in both languages. Of the form of the book, and the method of NO. 2828 , vOL. I I 37 